\title{
Acute Atrial Fibrillation Developed after Consumption of Alcohol Mixed with Energy Drink
}

\author{
(DEmin Uysal',(1) Hakan Çelik',(1) Süleyman Solak'
}

'Department of Emergency Medicine, University of Health Sciences Bagcilar Training and Research Hospital, Istanbul, Turkey

\begin{abstract}
Energy drinks are mostly consumed for joy and to, increase physical performance and attention. The popularity of consumption of energy drinks mixed with alcohol is increasing every day. Consumption of such mixtures could result in cardiac arrhythmias or even cause cardiac arrest. In this case report we present a young and healthy male patient with a complaint of palpitations, who developed acute atrial fibrillation after consumption of alcohol mixed with energy drink.

Keywords: Energy drink, alcohol, atrial fibrillation, young adult
\end{abstract}

\section{Özet}

Enerji içecekleri çoğunlukla zevk almak, fiziksel performansı ve dikkati arttırmak için tüketilir. Enerji içeceği ile karıştıılan alkol tüketiminin popülaritesi her geçen gün artmaktadır. Enerji içeceği ile karıştıılan alkol tüketimi kardiyak aritmileri kolaylaştırabilir hatta kalp durmasına neden olabilir. Bu olgu sunumunda çarpıntı şikayeti ile gelen, sağlıkı ve genç bir erkek hastada enerji içeceği ile karıştırılan alkol tüketimi sonrası gelişen akut atriyal fibrilasyon olgusunu sunuyoruz.

Anahtar Kelimeler: Enerji içeceği, alkol, atrial fibrilasyon, genç erişkin

\section{Introduction}

Today, the consumption of energy drinks is increasing among young people with the assumption the energy drinks are harmless. Although the main active ingredient in energy drinks is caffeine, there are different components such as taurine, inositol, riboflavin, pyridoxine, nicotinamide, other vitamin B derivatives and other herbal derivatives ${ }^{1}$. High concentration of caffeine is considered as the main cause of the harmful effects, although the unwanted effects of the energy drinks are not entirely known. Consumption of a mixture of energy drink and alcohol may result in cardiac arrhythmias, especially atrial fibrillation ${ }^{2}$. We aimed to present a case of a young, healthy man with acute atrial fibrillation after consumption of an energy drink mixed with alcohol.

\section{Case Report}

A 29-year-old male patient presented to the emergency department with complaint of tachycardia. No history of chronic diseases and drug use obtained. The patient reported an intake of a mixed drink using four cans of an energy drink and also four glasses of vodka for the New Year's Eve party and slept late night. He was awakened by the palpitations at about 14:00 o'clock on the next day. He denied use of any stimulating drugs. His vitals were as following blood pressure of $100 / 70 \mathrm{~mm} / \mathrm{Hg}$, the heart rate of $162 / \mathrm{min}$ and the respiratory rate:18/min. The apical heart sounds on auscultation were found irregularly tachycardic. On the electrocardiogram a trace of atrial fibrillation with rapid ventricular response was observed (Figure 1).

The patient's cardiac biomarkers, serum electrolytes, and thyroid function tests were normal. There was no metabolic acidosis in the patient's arterial blood gas. The cardiologist performed an echocardiogram upon our consultation, which showed a normally functioning heart with no anatomical abnormality. The patient's was on a rhythm monitor and a medical cardioversion was planned with 300 $\mathrm{mg}$ amiodarone intravenous infusion within 150 milliliters of $5 \%$ dextrose for thirty minutes. Following the infusion, the patient's heart rate returned to normal sinus rhythm with a heart rate of $72 / \mathrm{min}$ (Figure 2). A maintenance infusion of $900 \mathrm{mg}$ amiodarone within a solution of 500 milliliters $5 \%$ dextrose was administered within 24 hours. Following an uneventful rhythm and vital monitoring for a day, he was discharged and his cardiology follow up was planned.

Corresponding Author: Emin Uysal e-mail: dreminuysal@hotmail.com 


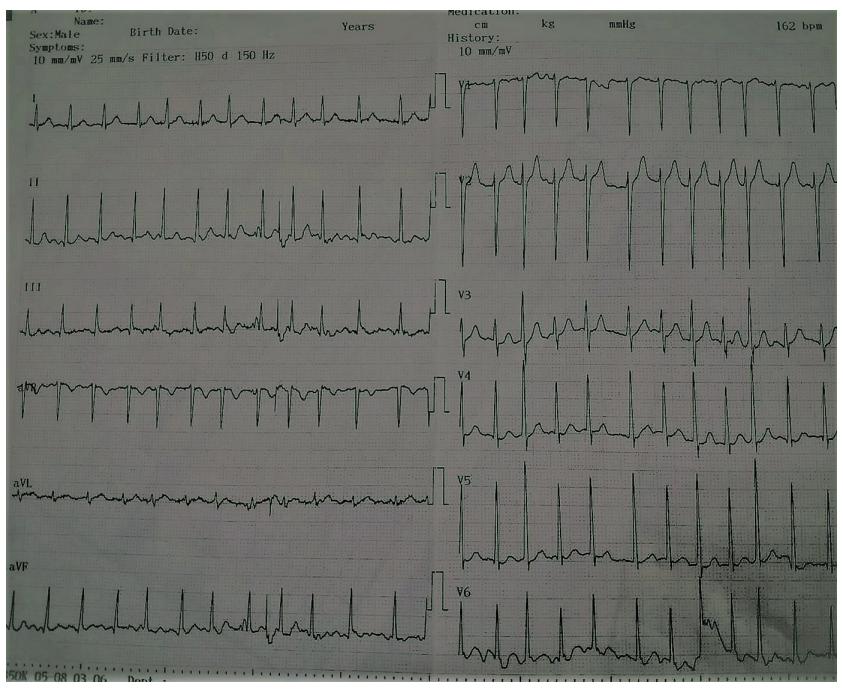

Figure 1. The electrocardiograph showed atrial fibrillation with high ventricular response.

\section{Discussion}

Energy drink consumption is increasing worldwide every year. Companies market their energy drinks by advertising of their effects on physical and emotional endurance and also increased mental focus. One of the most popular energy drinks, Red Bull ${ }^{\circledR}$ was first consumed in Austria in 1987 and started to be consumed in the United States in 1997. Energy drinks are now consumed in more than 160 countries $^{3}$. A $250 \mathrm{ml}$ typical energy drink contains $80-300 \mathrm{mg}$ of caffeine (this may also be derived from pure caffeine, guarana and / or other natural caffeine sources such as yerba mate), 1000 $\mathrm{mg}$ taurine, $60 \mathrm{mg}$ glucoronolactone, $40 \mathrm{~g}$ sugar (glucose/ sucrose ) and may also contain B group vitamins, ginseng, gingko biloba, L-carnitine and creatinine. Mixing energy drinks (such as 'Red Bull@') with alcohol (typically vodka or Jägermeister) is becoming increasingly popular, especially among young people ${ }^{4}$. Mixing alcohol with energy drinks can mask symptoms of alcohol intoxication, resulting in increased alcohol intake, dehydration, more severe and prolonged hangover, cardiovascular problems (such as palpitations) and alcohol intoxication. When alcohol drinks and energy drinks are combined, it can trigger the development of atrial fibrillation in young patients ${ }^{5}$. This effect may be caused by the synergistic effect of caffeine and other substances in energy drinks together with alcohol' ${ }^{6}$. In our patient, we attribute the development of acute atrial fibrillation to his consumption of 4 glasses of vodka and 4 energy drinks together. Intravenous hydration and antiarrhythmic treatment is generally effective in such cases of atrial fibrillation. Consumption of alcohol mixed with energy drink can also cause benign complications such as atrial fibrillation and sudden arterial blood pressure elevation, or malignant complications such as acute long QT syndrome, acute coro-

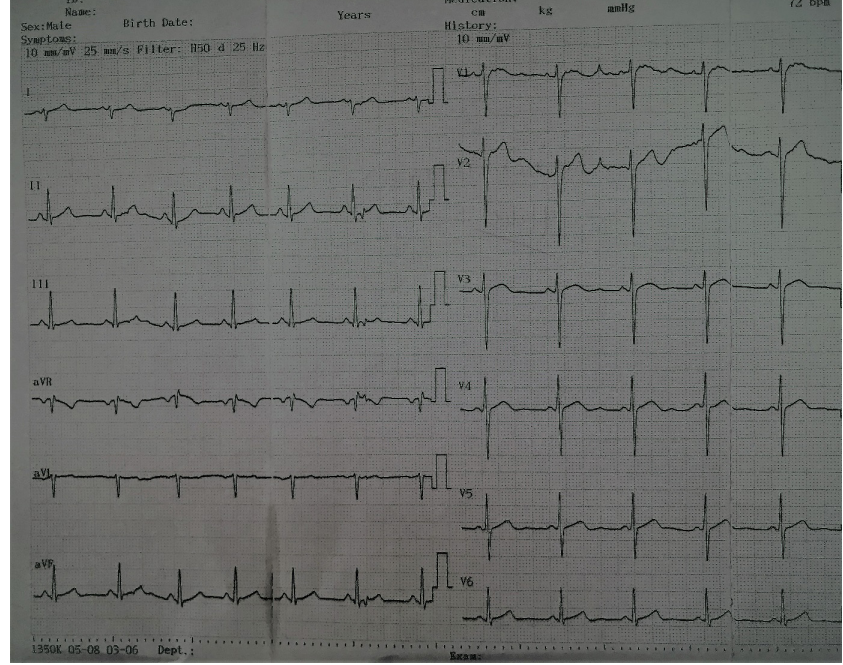

Figure 2. The electrocardiograph showed a normal sinus rhythm recorded following intravenous amiodarone infusion.

nary syndrome or even sudden cardiac death. This latter risk can be augmented by the energy drinks detrimental effects on platelets and endothelial function with secondary hypercoagulopathy ${ }^{2}$.

\section{Conclusion}

Physicians should keep in mind that consumption of alcohol mixed with energy drink in the young population has an arrhythmogenic potential. Furthermore, in the diagnostic procedure of acute cardiac events the causes of which are unknown, consumption of alcohol mixed with energy drink should be suspected as exogenous agents.

\section{References}

1. Görgülü $Y$, Taşdelen Ö, Sönmez MB, Çınar RK. A Case of Acute Psychosis Following Energy Drink Consumption. Noro Psikiyatr Ars. 2014;51(1):79-81.

2. Mattioli AV, Pennella S, Manenti $A$, Farinetti A. Energy drink overconsumption can trigger atrial fibrillation. J Cardiovasc Med. 2016;17:902-4.

3. Andrea U, Sophie HH, Alexandra L, Stephanie D, Eleonore P, Sugarka $F$, et al. Effects of alcohol mixed with energy drink and alcohol alone on subjective intoxication. Amino Acids. 2013;45(6):1385-93.

4. Pennay $A$, Lubman $D$, Miller $P$. Combining energy drinks and alcohol - a recipe for trouble? Aust Fam Physician. 2011;40(3):104-7.

5. Mattioli AV, Pennella S, Farinetti A, Manenti A. Energy drinks and atrial fibrillation in young adults. Clin Nutr. 2018;37(3):1073-4.

6. Anna VM. Beverages Of Daily Life: Impact Of Caffeine On Atrial Fibrillation. J Atr Fibrillation. 2014;7(2):1133. 